\title{
Two-Lane Settlement of Syaria Economic Disputes Between Religious Court and National Syaria Arbitration Agency (BASYARNAS)
}

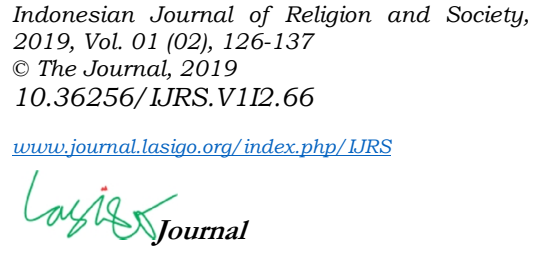

Article History

Received: September, $21^{\text {st }} 2019$

Revised: December, 27th 2019

Accepted: December, 30th 2019

\begin{abstract}
Anton Minardi
Ilmu Hubungan Internasional, FISIP, Universitas Pasundan, Bandung, Indonesia abdurrahmananton1975@gmail.com
\end{abstract}

\begin{abstract}
The development of the sharia economy, particularly in the banking sector, both domestically and abroad, is very encouraging. Because of his young age and lack of adequate understanding of various economic practices, Sharia opens the possibility of strife. When there is a Sharia economic dispute, there are two institutions that have the authority to handle the settlement, namely the Religious Court and BASYARNAS. Both institutions, both the religious court and BASYARNAS, have advantages and disadvantages in handling Sharia economic disputes. Openness must be developed from various parties who prefer Islamic shura (consensus) in determining everything and solving problems. Through Shura disputes can be resolved satisfactorily, can still maintain the privacy of the parties, the closer the relationship between the parties, the time can be shortened, the more costeffective, and the relationship between the parties can be improved better. If you see that the resolution of economic disputes through BASYARNAS Syariah can be submitted before resolving disputes through the Religious Courts. Considering the new Shariah economic practices, it still needs to be disseminated in addition to the implementation of sharia economics, it also requires human resources and top-class facilities, as well as a complete constitutional and operational foundation.
\end{abstract}

Keywords: economic sharia; dispute settlement; religious court; BASYARNAS

\section{Introduction}

The economic development of Sharia can not be separated from the part of the community effort to get the welfare of the corresponding Sharia Islam. It can be seen with the rampant practice muamalah (transactions) that uses both the Islamic Sharia in personal affairs, family and socio-economic. The practice of Muamalah based on Islamic Sharia such as Sharia banking, not only grew in Muslim countries but also in countries that are predominantly non-Muslim.

Muamalah practices based on Islamic Sharia to be found other than in marriage, inheritance, wills, grants, endowments, charity, infaq, and is in economic Sharia which include Sharia banks, microfinance institutions Sharia, insurance Sharia, Sharia reinsurance, mutual funds Sharia, Sharia bonds and commercial paper, medium-term Sharia, securities Sharia, Sharia financing, mortgage Sharia, pension funds Sharia financial institutions Sharia, and business Sharia (UU-RI, 2009b). Although the ideals of goodness muamalah practice go far beyond the economic practices of communist, socialist or liberal, still there are some problems in practice. These problems can arise because the practice

Corresponding Author

Name : Anton Minardi

Email : abdurrahmananton1975@gmail.com 
muamalah by Islamic Shari'a is still relatively new, an understanding of the Islamic Shari'a was still minimal, and awareness to actual practice the Islamic Sharia should kaffah also still was minimal.

Dispute resolution in practice muamalah by Islamic Shari'a according to Law No. 50 of 2009 on the Religious Courts can be resolved through the Religious Courts. Settlement of disputes according to Law No. 30 of 1999 on Arbitration and Alternative Dispute Resolution agreed to dispute parties can also be resolved through arbitration. Disputes can be settled through arbitration any dispute which arises in the case of controlled entirely by the parties to the dispute parties (UU-RI, 1999). The settlement of economic disputes in the Court is less in the interest of the economic actors, because of a long time, the limited resources and the results of the win-loss cause damage to future business relations. Resolution of arbitration disputes is an alternative choice (Triana, 2018a).

However, for some reasons especially in legal certainty, Religious Court is still as prime choice. First, the establishment of a special syariah economic court within the Religious Courts can achieve efficiency and professional realization so that the belief of sharia economic community towards the Religious Courts is realized. Second, the construction of the special law court of Islamic law within the Religious Courts is the 1945 Constitution and Law Number 48 the Year 2009 on Judicial Power, and the position within the Religious Courts under the Supreme Courtin accordance with Law No. 3 of 2006 on Amendment to Law Number 7 of 1989 concerning Religious Courts jo Law Number 50 Year 2009 concerning Second Amendment to Law Number 7 Year 1989 on Religious Courts (Manik, Yaswirman, Azheri, \& Ikhwan, 2017).

There are still alternatives to the resolution for syariah economic dispute, especially in muamalah finance. While the National Sharia Council Number 07/DSN-MUI/IV/2000 explained that the settlement of murabahah financing disputes in the Syaria Arbitration Board. According to Article 55 of Law No. 21 of 2008 concerning Sharia Banking, that sharia dispute resolution can be carried out by the Court within the religious court and can also be resolved by referring to the contents of the contract. In fact, murabahah financing contracts entered into by genuine partner cooperatives do not explicitly designate which judicial institutions to settle them (Anwar, Yaswirman, \& Ulfanora, 2019).

The previous dispute settlement according to Islamic Sharia review is based on the Qur'an, among others surat Al Hujurot (49) of paragraph 9 and surat Nisa (4) Paragraph 35 and Sunnah are the narratives An Nasa'i, then on the 5th Jumadil Beginning $1414 \mathrm{H}$ coincide with the October 21, 1993 the Indonesian Ulema Council (MUI) established the Arbitration Board Muamalat Indonesia (BAMUI) which later on 30 Shawwal 1424 December 24, 2003 to coincide with Decision Letter MUI MUI No. Kep-09/MUI/XII/2003 changed its name to the National Sharia Arbitration Board (BASYARNAS) (Winata, 2012).

\section{Method}

This research began through a literature study with a comparative method of searching which is a more effective way between BASYARNAS and the Religious Court with descriptive analysis. This research provided data from various references and also from the staff and expert of the institutions and also from staff and experts from related institutions and also attention to the cases occurred. Sharia dispute resolution authorities like that there are two lines or Double Lane although both will also lead to the Supreme Court if could not be resolved in mediation in BASYARNAS. The question that arises with this two-track dispute resolution will facilitate dispute resolution? What will help each other? Which path is a more effective and efficient way to resolve disputes Sharia?

In order for this research focus, the authors restrict research in economic dispute resolution Sharia in Islamic Court and Basyarnas. The research objective is to seek answers on how to resolve disputes Sharia economy in Indonesia, and which path is more effective and efficient in resolving disputes between the economy Sharia Islamic Court and Basyarnas. This study uses normative juridical approach to make comparisons between the economic dispute resolution in Islamic Court and BASYARNAS. The presentation uses normative juridical analysis with a holistic analysis, which is an approach that relies on the study of the law relating various sciences includes sociology, politics and economics (Bahder, 2008).

Research conducted in reference research (research literature) and has been done through interviews with competent resources is expected to be able to represent the Islamic Court and BASYARNAS in particular and the general public and activists. The location is in a collection 
of secondary data research conducted in several libraries and related institutions in Bandung and Jakarta. In addition, interviews were conducted with competent parties in the application of Islamic Sharia and dispute resolution both academics, community leaders, judges, stakeholders in communities around Bandung and Jakarta. The study was conducted in 1 year from 2014 to 2015.

\section{Theoretical Framework}

The increasing number of people, increasing the amount and the faster the activity, the interaction between each other in the fulfilment by the agreement, the agreement, cooperation, investment, and trade. The greater the number of interactions and increasingly heavy frequency of transactions in various fields raises the possibility of disputes that require handling and settlement of a fast, effective (targeted and fast process) and efficient (minimal cost).

Islamic Sharia anticipates problems and disputes, although sometimes can not avoid the occurrence of problems and disputes. Disputes in the Islamic Sharia, in general, can be completed in two ways, namely deliberation process in the form of mediation in an effort to anticipate things that are not desirable, and tahkim (judge) something that has happened by Islamic jurists (judges). Islamic Sharia dispute resolution, especially in the economic field of Sharia in Indonesia can be reached via a double track is through the Religious Courts (Winata, 2012) and Arbitration (UU-RI, 1999) in this case by BASYARNAS. Settlement through the Religious Courts generally considered less effective and efficient because it takes a long time to remember a lot of cases they handle and ultimately the cost will also be more expensive.

In business, whether based on conventional or sharia, conflict or dispute sometimes happens and can not be avoided. The settlement of disputes in the Court, takes a long time, the cost is huge and the result is a win-lose, resulting in a sense of unfairness to either party. For that Sulh (peaceful) in resolving the dispute sharia economy becomes the choice of the sharia economic actors if there is a dispute between the parties. Sulh (peace) can be developed with various models, such as negotiation, mediation or arbitration. This dispute resolution model is more acceptable to the society, because philosophically the values of Sulh (peace) already exists intrinsically in the culture of Indonesian society which prioritizes deliberation and harmony in the life of society (Triana, 2017).

Mediation through the religious court is still achieving a low success rate in Indonesia, from 2003 to 2015. Based on the results of the study, data shows that the maximum achievement is only $18.1 \%$. This study aims to determine the repositioning of the mediation process in resolving Islamic financial dispute through the Religious Courts after the enacment of Supreme Court Regulation No. 1 of 2016 (Musjtari, Radliyah, \& Riyanto, 2019).

Alternative dispute resolution through arbitration will be considered more efficient because it does not have to wait long in the solution, so as to reduce the cost incurred. Religious Court judgment which has the force of law still can be directly executed, while the award was not implemented voluntarily by the parties to the dispute can be submitted to the District Court to execute court decision on the request of either party to the dispute. Here occur inconsistencies in Islamic Sharia dispute resolution through arbitration. Islamic Sharia authority that should exist in the Islamic Court, but in case the parties do not make the results of voluntary arbitration, either party is required to register the execution to the District Court (UU-RI, 1999).

This dualism is confusing, as showing that the District Court 'not willing to' give authority to enforce Sharia Islamic Religious Court is not given full authority to enforce the Islamic Shari'a. However, strictly in accordance with Act No. 50 of 2009 on the Religious Courts that religious court has broad in resolving disputes, including disputes in the economic muamalah Sharia (UU-RI, 2009b). It was also confirmed in the Sharia banking dispute with the birth of the Constitutional Court Decision No. 93 / PUU-X / 2012 which cancels an explanation of Article 55 of the Law Sharia banking, which stated that the Sharia banking disputes resolved through the Religious Courts. Indeed they should have the authority given to the religious court in accordance wording of Article 55 of Law No. 21 of 2008 concerning Sharia Banking namely: "Sharia Banking Dispute resolution carried by the court within the Religious Courts".

Islamic banking dispute can be resolved through the two institutions. The first is litigation path or resolution through the court process and the second is the non-litigation path or BASYARNAS. The Board authority to examine and to decide disputes in sharia banking is based on the contract agreement of the parties. Therefore, the court is not 
entitled to review and to determine a case of sharia banking if it has been delegated to the arbitration institution based agreement because it is the choice of the parties to resolve disputes (Masse \& Rusli, 2018).

Several findings are found. First, the use of Article 59 Law No. 48 of 2009 on the Judicial Power and the neglect of Article 49 Law No. 3 of 2006 on the mendment of Law No. 7 of 1989 on the Religious Court and Article 55 Law No. 21 of 2008 on Sharia Banking as a reference for the Basyarnas verdict execution is based on philosophical, historical, political, and juridical argument. Second, the norm of the Basyarnas verdict execution relevance with the legal purpose is vague, as associated with justice, legal certainty and benefits aspects. Third, there are two legal principles to resolve conflicts on norms of the Basyarnas verdict execution, namely (a) the principle of consistency, and (b) the principle of the obligatory to avoid authoritarianism of the elite positive norm (Yasin, Munir, Sukarmi, \& Sahibuddin, 2016). Based on the elaboration above, the position of the Religious Courts in addition BASYARNAS as an economic alternative dispute resolution to resolve disputes Sharia Sharia economy has been solid. Furthermore, the authors compare the effectiveness and efficiency of economic dispute resolution Sharia through the Religious Courts and BASYARNAS.

\section{Resolution of Economic Disputes Sharia through the Religious Courts in Indonesia}

Islamic justice in Indonesia, hereinafter referred to as "Religious Court", has existed in various places in the archipelago, long since the Dutch colonial era. According to court historians, Religious Court has existed since the 16th century. In history, dated January 19, 1882, was designated as the anniversary, which coincides with the enactment ordonantie Gazette. 1882152, concerning the Religious Courts in Java and Madura (Rasyid, 2010). Institutional religious courts stipulated in Law No. 7 Tahun 1989 of Religious Justice. In regards to Article 6 of the institutional, religious courts consist of two levels, namely: religious courts as courts of the first instance and the Court as a religious high court of appeal. Religious Court as the court of first instance court is acting to receive, examine, and decide upon any request or claim at the earliest stage and bottom. Religious Court as a judicial act in everyday accommodate at an early stage and to decide or judge at an early stage any case filed looking for justice. None of the community may submit a request or complaint directly to the Court of Religion.

All types of cases must first through the Religious Court in its capacity as court petition or firstly sued. To all cases referred to it in its capacity as a court of the first instance, should receive, examine, and decide upon, forbidden refused to receive, examine, and decide cases submitted to it under the pretext of this. It has been clearly stated in Article 56 that "The court may not refuse to examine and decide a case filed under the pretext that the law does not or less clear, but shall examine and decide upon its obligatory" (Structure and Authority of Religious Cout).

\subsection{Dispute Settlement Mechanism}

The legal process in the same religious court process in the District Court. It is stipulated in Article 54 of Law No. 3 of 2006 on the Amendment of Act No. 71989 about the Religious Court, stating that: "The procedural law applicable to the religious courts are civil procedural law applicable in the courts in general courts, except as specifically regulated in this law". The civil procedure law as applicable in the general court, HIR (Het Herzeine Inlandsche Reglement) and R.Bg (Rechts Reglement buitengewesten) including the provisions stipulated in Rv (Reglement of de Rechtsvordering), the Civil Code, Act No. 4 Year 2004 on Judicial Power, Law No. 5 of 2004 concerning the Supreme Court and Law No. 8 Year 2004 on the General and other related regulations.

The civil procedure law as applicable in the general court, HIR (Het Herzeine Inlandsche Reglement) and R.Bg (Rechts Reglement buitengewesten) including the provisions stipulated in Rv (Reglement of de Rechtsvordering), the Civil Code, Act No. 4 Year 2004 on Judicial Power, Law No. 5 of 2004 concerning the Supreme Court and Law No. 8 Year 2004 on the General and other related regulations. The first step in resolving disputes in the Religious as well as the District Court that peace through mediation. This is stipulated in Article 154 R.Bg/130 HIR and Perma No. 1 of 2008. Article 1, point 7 PERMA states that: "a way of settling disputes through the negotiation process to obtain the agreement of the parties with the assistance of a mediator". Stages of dispute resolution in the Religious Court include Registration, Mediation, if there is no peace continued to stage, Trial from Inspection, 
Description of the parties, Description of the witnesses and experts to Reply and Rejoinder, then Consultative Panel of Judges, Reading of Decision and Execution Decision.

The second step if peace can not occur, then in order to bring justice Judges examine the case and request information from the parties and witnesses in the trial if necessary. Furthermore, the decision was made Judge provide justice for the people. Dispute resolution in the Religious Courts as in State Courts sometimes there is no time limit it, the cost is dependent on the process through. So it is common to take years and cost very high. Disputes recorded in the Religious according to information from the Director-General of the Religious Courts Supreme Court Republic of Indonesia (Purwosusilo, 2013): In 2012 nationally, the number of cases handled by the PA / MS during the year 2012 amounted to 476961 . While the case on appeal, (for example) is handled PTA / MS Aceh only amounted 2.533. The number of the case on appeal and Review of the smaller back again. It shows the people's trust and satisfaction is very high toward the religious court.

\subsection{Settlement of Disputes through Arbitration Islamic Sharia Nation Sharia (BASYARNAS) in Indonesia}

Arbitration institution is always required in addition to the judiciary, as BANI Indonesian National Arbitration Board: founded by the Chamber of Commerce in 1977) remain in demand despite existing eternity since the District Court, High Court and Supreme Court (BASYARNAS, 2014). Therefore BASYARNAS (National Islamic Arbitration Board: founded by the MUI in 1993) is always necessary although later religious court was authorized to complete, examine and decide the dispute in the field of Islamic economics (Amendment Act No. 7 of 1989). Compared with the judiciary (including religious court), arbitration institution chosen by the people seeking justice because it has many advantages. Excess arbitration institution rather than the judiciary, among others are: the examination process is simple, closed, fast and dignified.

National Sharia Arbitration Board (BASYARNAS) of the establishment named Arbitration Muamalat Indonesia (BAMUI). BAMUI established on 21 October 1993 - The Foundation subsequently incorporated by Indonesian Ulama Council (MUI) Decree No. Kep-09 / MUI / XII / 2003 dated December 24, 2003 turned into BASYARNAS. BASYARNAS domiciled in Jakarta with branches or representatives in other places deemed necessary. It has some legal basis, comprises Al-Quran; Sunnah; Ijma'; Act 30 of 1999 on Arbitration and Alternative Dispute Resolution, MUI Decree No. Kep-09 / MUI / XII / 2003 dated December 24, 2003; DSN Decree-MUI.

\subsubsection{The Authority of BASYARNAS}

BASYARNAS have speciality in: First, resolve disputes fairly and quickly muamalah (civil) arising in the field of commerce, finance, industry, services and others that according to the law and regulations are fully controlled by the parties, and the parties agree in writing to submit the solution to BASYARNAS in accordance with the procedure BASYARNAS; Second, give a binding opinion at the request of the parties without the existence of a dispute regarding the issue with respect to an agreement.

\subsubsection{Arbitration Procedure}

National Sharia Arbitration Board (BASYARNAS) have rules of procedure which contains provisions, among others including Application to conduct the arbitration, Determination of the arbitrator, Events examination, Peace, Evidence and witnesses, The end of the examination, Decision making, Fixes Decision, Cancellation of the decision, Decision Registration and Implementation of the decision (execution).

\subsection{Case Settlement of Sharia Economy Dispute through the Religious Court and BASYARNAS}

\subsubsection{Case Settlement through the Religious Courts}

There has been a dispute between a customer of Bank Mega Indonesian Sharia named Nining Rohayati Bint Waslam with Proxy Jaenurdin, SH. (Plaintiff) with Sharia Bank Mega Indonesia with Attorney Risky Aditiaresi, F. Ismail Tri Murdjaka, SH. and Sri Sawuri Ratnapuri, SH. (Defendant). Plaintiff has filed a lawsuit on December 2, 2009 and enrolled in the Religious Bandung with number: 3066 / Pdt.G / 2009 / PA.Bdg December 3, 2009. Against this case has been born Bandung Religious Court Decision No: 3066 / Pdt.G 
/2009/PA.Bdg which was decided in the next year is Monday October 11, 2010. Which basically contains: Passing, which consist of Reject the Plaintiff's claim in its entirety and Charge the entire cost of this case to the Plaintiff, Rp 441,000, - (four hundred and forty thousand rupiahs).

Furthermore, Plaintiff did appeal to the High Court of Bandung Religion and the birth date of February 14, 2011 Decision No. 10 / Pdt.G / 2011 / PTA.Bdg which basically contains: Passing, which consist of Declare, that the appeal filed by the Appellant formally acceptable and Cancel the court ruling Religion Bandung on October 11, 2010 to coincide with the date of the M 3 Dzulqo'dah 1431 Number: 3066 / Pdt.G / 2009 / PA.Bdg. who filed the appeal.

Furthermore, Plaintiff act to the appeal dated March 29, 2011 and on December 5, 2011 was born Decision Number: 492 K / AG / 2011, which essentially contains: Passing, which consist of Reject The appeal of Cassation Nining Rohayati the Waslam daughter and Appeal Cassation / Plaintiff to pay court costs in this appeal is Rp 500.000, - (five hundred thousand rupiah);

\subsubsection{Case of Economic Dispute Resolution through BASYARNAS}

At present, the Indonesian economic system recognizes and applies Sharia principles in the National Legal System. The principles are based on the value of justice, mutuality, equality, benefit and universalism (rahmatan lil 'alamin), especially in the agreement (Akad). The contract is affixed with a notarial deed, the the parties are deemed to have approved the content and its consequences. If one of the parties does not perform his obligation, there can emerge a dispute in the implementation of Sharia economic transactions. Therefore, the position of a notary deed is very important as an evidence in the dispute settlement (Masriani, 2016).

There has been a dispute between bank customers (Plaintiff) with a bank (Defendant), Plaintiffs are not satisfied with the Defendants in the case of a loan of USD 878791366 , -. The names of the parties withheld pursuant to Article 27 of Law No. 30 of 1999 which states: "All dispute by the arbitrators or arbitral tribunals shall be conducted in private". The process at BASYARNAS takes a maximum of around 6 months, at a cost that is agreed by the parties.

The decision of the National Islamic Arbitration (BASYARNAS) No. 16/2008 / BASYARNAS / ka.Jak which essentially contains: In Exception: To declare defendant can not be accepted. In Essential Case, To grant Petition in part, To declare that Respondent did breach of contract, To declare Void Murabahah Financing Agreement date February 23 made by and in front Efran Yunianto, SH, Notary in Jakarta, To punish defendant to return to Plaintiff money amount Rp.878.791.366, (eight hundred and seventy-eight million seven hundred and ninety-one thousand three hundred and sixty-six Rupiah) consisting of:

a. Banks charge fees Payment Rp.350.000.000, - (three hundred fifty million Rupiah) or $1 \%$ (one per cent) from the value of the financing facilities totalling Rp.35.000.000.000, - (thirty-five billion Rupiah) Murabaha agreement declared null and void because of the law;

b. Payment of insurance money project (PT. Asuransi Dayin Mitra) totalling Rp.45.027.000, - (forty-five million twenty-seven thousand Rupiah);

c. Advance payment Social Security contributions Rp.5.962.700,- totalling (Five million nine hundred and sixty-two thousand seven hundred Rupiah);

d. d. Payment of the fees to Arrangement and Building Control Service Jakarta Provincial Government of Rp.298.135.000, - (two hundred and ninety-eight million one hundred thirty-five thousand Rupiah);

e. Money repayments Rp.179.666.666 some margin, - (one hundred and seventy-nine million six hundred and sixty-six thousand six hundred and sixty-six Rupiah).

To punish Respondent to return to the Applicant costs Cost The fee is supported by other evidence all costs proof expenditure which has been verified by a public accounting firm regarding the truth from, whether about the authenticity of Standard and Poor evidence or about the cost;

Resolve that public accounting firm tasked to perform Verification of the costs that have been incurred by the applicant is a public accounting firm approved by the Applicant and the Respondent within 30 (thirty) days from the verdict of the Council read. -Resolve if the Petitioner and the Respondent failed to reach agreement on the appointment 
of the Public Accounting Firm waktu30 term (thirty) days, the appointment of public accounting firm will be made by the Assembly after the Assembly to obtain a report from one of the litigants, that or of the Applicant or from the Respondent.

Resolve the cost of the public accounting firm, both appointed by the Applicant and the Respondent and appointed by the Assembly borne by the Applicant and the Respondent respectively by $50 \%$ (fifty per cent).

Reject Application for applicants to carry out sequestration, Reject The petition for forces money (dwangsom), Declare This decision is final and binding (final and binding) and has legal force since it was pronounced so, therefore, it cannot be cancelle through any legal remedy. -The remainder of the Petitioner demands, Punish the Respondent to carry out this decision no later than 30 (thirty) days since the pronouncement of this decision.

To charge Costs incurred in this case the Applicant danTermohon respectively $1 / 2$ portion of the costs of this case, Resolve That if the Respondent rejected both by means of silence or conduct legal measures Aimed at the cancellation of this decision, Among others, by filing an objection or create a new lawsuit over religious court or the General Court so that the execution of this decision be delayed let alone be erlarut-soluble, then the applicant may file complaints and appeals Bank Indonesia to impose administrative sanctions and reduce health and Bank Indonesia must be based on the legal force of this decision meets the petition are Reviews such that.

To order the Secretary of the Assembly as an official referee to Register the arbitration award derivative at the Registrar's Office specified in the Central Jakarta Religious Court deadline as Law 30 of 1999concering Arbitration and Alternative Dispute Resolution in conjunction with the High Court No. 08 Date 10 October 2008 (Central Jakarta Religious Court, 2009).

\section{Resolution of Economic Disputes Sharia in Indonesia}

Sharia economic development in Indonesia is encouraging and be thankful for, especially in the field of Sharia banking. According to the Director General for Religious Courts Supreme Court, Islamic economic development in Indonesia is growing unusually rapidly (Purwosusilo, 2013). Even Indonesia is the biggest Islamic retail banking. Along with the rapid development, the Islamic economic disputes will also be more and more. Disputes that later settled in religious courts.

At the time the writer doing research in Public Relations (PR) Bandung Islamic Court stated that the economic disputes Sharia is still very minimal. This was evidenced by the small number of complaints each year dispute in his community to the religious court, especially in the city. So even according to the staff BASYARNAS (Basyarnas Staff, 2014) that since its establishment until 2014 economic dispute resolution Sharia new Islamic banking in particular there are about 20 cases. Thank God all disputes can be resolved through peace.

Sharia economic dispute resolution is demanded to be more professional in accordance with sharia, namely dispute resolution that is fast, affordable and satisfies a sense of justice for the community. Dispute settlement in economic Sharia very noble mission and are required to maintain excellent performance, because according to the Sharia economic vision is to bring a more favorable economic system, fair, safe and be rahmatan lil alamin. Implementation of Sharia are not diehard economy (overall) in fact has given rise to a negative effective that as no different from the economic system of usury that only benefit the parties alone. Similarly, if the Sharia economic dispute resolution professionals who do not fit the Islamic Sharia will only cause negative effects for businesses of Sharia, people who take advantage of economies of Sharia or the subject of criticism for those who do not like the economy Sharia.

Indonesia's 2 tracks (track) Sharia economic dispute resolution is through track Religious Courts and Arbitration National Sharia (BASYARNAS). The Religious Court represent the authority of the judicial institutions which have not applied sharia principles. While the presence of Basyarnas an alternative dispute resolution Sharia economy is expected to reduce the accumulation of cases in the courts of Religion and expected more simple while maintaining privacy (confidential) the parties to the dispute.

The path of resolving Sharia economic disputes through the Religious Courts in Indonesia has been established because the Religious Courts are an established institution and lead professional judges. But because it uses the same legal process as the General Court which still uses the legal basis of the colonial and civil legacy has been felt to have a 
negative impact on the economic value of Sharia dispute resolution itself. For example, in the absence of a specified period in dispute resolution which must take a long time and high costs which ultimately take a lot of other things. Including because of the nature of justice that is open to the public, it will cause case information to be published to various groups. It might cause a loss in the form of a negative image to the disputing party. However, peace efforts in the early stages of dispute resolution at the Religious Courts are expected to cover up image disputes that are always long and expensive.

The track settlement of disputes through alternative dispute resolution BASYARNAS as non-litigation since the beginning is formatted for easy, low cost and maintain the privacy of the parties is to be strengthened. The period of the longest within 180 days ( 6 months) is a convenience, reduce costs and at the same time benefit for the community, especially Sharia economic actors. But can also be negative when the result of the arbitration is not in line with expectations for the quality of the arbitrators who lack experience, and execution of the arbitral award which is less powerful. Nevertheless, the execution of the judgment can be reinforced by the order of execution of the Chairman of the Religious. Thus in addition to fast, low cost and powerful in arbitration decision execution.

Its jurisdiction is seen as fluctuating, especially in resolving Islamic economic disputes. Although Article 18 and Article 25 of Law no. 48 of 2009 concerning Judicial Authority states that the Supreme Court is responsible for 4 (four) under the court, general court, religious court, administrative court and military court. Indeed, based on the law in any court that has jurisdiction to adjudicate the judicial environment (diversity jurisdiction) is absolute in the field of each jurisdiction.

If in the case filed by the Applicant to the Islamic Court can be directly addressed to the bitter end, but in the case of dispute resolution is done through execution BASYARNAS Decision still occur attraction authority. The absolute authority of the judiciary in the field of jurisdiction did not automatically make the Religious Courts absolute authority in Sharia economic settlement. Whereas Article 49 of Law No. 3 of 2006 on the Religious Courts that have been refurbished into Law No. 50 of 2009 on the Religious Court stated that the religious court competent to deal with in the case of marriage, inheritance, wills, grants, endowments, charity, infaq, and shodaqoh economy is in Sharia. Even gave the Appellate Court (SEMA) No. 8 of 2008 on Arbitration Decision Execution Sharia point number 4, the more states that: "In the case of Sharia Arbitration Board's decision was not implemented voluntarily, then the decision is implemented based on the command chair of the competent court at the request of one party to the dispute and therefore in accordance with Article 49 of Law No. 7 of 1989 as amended by No. 3 of 2006 Islamic Court also assigned and authorized to examine, decide and resolve the case in the field of Islamic economics, the President of the Court ordered the execution of religion that authorized Arbitration decision Sharia" (SEMA (Supreme Court Sentence) Number 8 Year 2008, 2008).

But after the birth the Appellate Court (SEMA) No. 8 of 2010, which cancels (SEMA) No. 8 of 2008, which contains the execution of the decision of the National Islamic Arbitration Board (BASYARNAS) which is the authority of the religious courts, then based on Article 59 paragraph (3) Law No. 48 Year 2009 concerning Judicial Authority stated in terms of the parties do not implement the decision of the arbitration (including sharia arbitration) voluntarily, then the decision (arbitration) is implemented based on the command chair of the district court, at the request of either party to the dispute.

In terms of implementing this decree, BASYARNAS caused confusion for law enforcement and confusion for justice seekers. If based on Law Number 48 of 2009 concerning Justice, specifically Article 59 paragraph (3) with the description and Law Number 30 of 1999 concerning Arbitration and Alternative Dispute Resolution, namely in Article 61 it is stated that in the case of the parties not implementing the arbitration decision (including Sharia arbitration) on a voluntary basis, decisions are made based on the head of a district court order, at the request of one of the disputing parties, and the same religious court has the authority to implement the BASYARNAS Decree (UU-RI, 1999, 2009a).

Alhamdulillah robbill alamin recent developments is the birth of the Decree (SK) The Constitutional Court No. 93 of 2012 (Religious Court Magazine, 2014) which cancels SEMA No. 8 of 2010, which stated that the authority to carry out the execution verdict BASYARNAS is on the order of the Chairman of the District Court cancelled. Decree No. 93 of the Constitutional Court returns the absolute authority of the religious court to deal with disputes or cases in the field of jurisdiction, namely the case of religion. thus its jurisdiction 
has been strong to handle those cases in economics Sharia and issued a writ of execution against the verdict BASYARNAS.

\section{Analysis Against Sharia Economic Dispute Resolution Practice in Indonesia.}

There are two traces in the resolution of Islamic economic disputes. First, through the religious court the second, through the National Sharia Arbitration Council (BASYARNAS). Dispute resolution through litigation is always time-consuming, expensive and results in a win and lose solutions. Therefore non-litigation resolution is an alternative choice (Triana, 2018b). Excess of economic dispute resolution through Religious Court track is as follows: First, Court has the human resources that already understand the problems of sharia, living to increase their insight and knowledge through education and training on a regular basis (Fahmudin, 2015).

Second, although a bill on Islamic economics has not ratified yet the Religious Courts have established sufficient substantive law, particularly with regard to economic sharia, including in the form of books of fiqh muamalah is contextual in its application. Third, the existence of the Religious Courts office almost covering all regions and the municipal districts throughout Indonesia and most of the landslide apply network Information Technology (IT) on the basis of the Internet, so when compared with BASYARNAS whose existence is still concentrated in the capital region, the Religious Courts have the advantage in easing service.

Fourth, it has the support of the majority of the Indonesian population, which at present the Muslim community has a high spirit in upholding their religious values. Fifth, there is strong political support for the government and the Parliament have agreed on the expansion of the authority of the Religious Court on 21 February 2006 that the enactment of Law No. 3 The year 2006 was a necessity to adjust to the demands of the existing law, such as paradigm shift from family courts to the modern justice. Sixth, support from the Banking Authority (Bank Indonesia) and support from Islamic Financial Institutions throughout the world.

The weakness of Sharia banking economic dispute resolution specifically through the Religious Court (Fahmudin) Are, First, Apparatus Religious Courts have a background that most of Sharia and legal disciplines lack understanding of economic activity both micro and macro, also activities in the field of the real sector, production, distribution and consumption. Second, Apparatus Religious Courts still less control of the activities of Islamic financial institutions to support the real sector business activities, such as: Bank of Sharia, Sharia, Islamic pawnshop, Multifinance, Capital Markets, and so on. Third, the low level of Religious Imagery which is seen as only struggling to deal with problems that are difficult to eliminate NCTR, it is the impact of the lack of support from relevant institutions to socialize Law 3 of 2006 in conjunction with Law 50 of 2009. Fourth, the existence of judicial institutions, especially the majority of judges who still do not understand (technological stuttering) is an obstacle for those who will resolve Islamic economic disputes, because Islamic economic knowledge for judges must always be up to date must be supported by them. the ability to access information from various media, especially through the internet. To anticipate this, Badilag seems responsive to continue to promote IT (Information Technology) contests for Religious Courts throughout Indonesia, say Badilag's skill level has received a positive response and most of the Religious Courts in Indonesia, have been proven to have trained. IT teams in most areas far from the capital. At least their IT contest was organized by Badilag to provide a stimulus for the strength of competing for religious judgments to access information through the internet.

While the economic advantages of dispute resolution Sharia through BASYARNAS (BASYARNAS, 2014) are: First, the arbitral tribunal carried out simply in one level - the level of the first and last - in a family atmosphere and (special arbitration sharia) in the framework of maintaining silaturrahim and ukhwuah Islamiyah. Second, the arbitral tribunal held behind closed doors (confidential) - do not open as a trial, so that the parties to the dispute and the dispute of material unknown to the public at large. Full disclosure of personal disputes and disputes both companies can bring down both the dignity, selfesteem and personal honour and the image and performance of the company. Third, the arbitral tribunal implemented faster. The arbitral tribunal should have taken the decision not later than 180 days ( 6 months). Compare with the trial court that often takes many years with no small cost. Forth, the arbitration decision is "final and binding" final and binding, there is no appeal and cassation - short, fast and efficient. Efficiency is greatly 
appreciated in all affairs, especially in the world of commerce. Fifth, the award has executorial strength. The arbitral award, if not carried out voluntarily, then the execution of the decision implemented by the command Chairman of the Court at the request of either party - such as a civil judgment on the legal system in general.

The shortage of Sharia economic dispute resolution through BASYARNAS are first, that this institution is still relatively new experience in resolving disputes, especially in the economic Sharia was not really tested. Second, the arbitrator is also despite coming from various backgrounds who are experts in their field but in understanding Sharia relatively new economy remains to be improved, the amount of the fee agreed by the parties can be a separate mental burden for the parties to proceedings in BASYARNAS because it is not defined by BASYARNAS but by the parties. Maybe the parties feel proud to establish a lowcost case, when in fact the court fee need not be expensive. Forth, decisions are not directly executed by the parties and require command Chairman of the Religious to carry out the execution of the arbitration decision raises less powerfully perception of this institution. Fifth, the new and relatively new arbitrators may not very well be known by the public, so that the level of confidence to these institutions is still not high.

Based on the explanation above, we got information that the first litigation process which is more religious gets legal certainty than in BASYARNAS. Second, but the process in Religion is too long, long and expensive, whereas in BASYARNAS it is simpler, easier and cheaper. Third, privacy at BASYARNAS is better protected than in open court. Fourth, the ability of judges in religious courts on religious matters is no doubt but economic cases may still need to be improved, while in BASYARNAS the arbitrators can be recruited from among experts and practitioners in the field of Sharia law and economics. Fifth, and if in religious equipment and facilities the organization's assembly is complete, BASYARNAS may still be refined.

\section{Conclusion}

After conducting research and discussion on Islamic economics, implementation and resolution of disputes in Islamic economics, the authors reach the following conclusions: 1). Applying rules is not always perfect, it can open up opportunities for disputes. Likewise in the application of Islamic economics. The implementation of Islamic economics also opens up the possibility of disputes, moreover, the application is still very new and still in the learning phase. But as perfect Islamic teachings always provide solutions that are solutions through syu'ro (the consensus of the disputing parties) and tahkim (the trial). In Indonesia, the second pathway (pathway) for dispute resolution is through the Religious Courts and the National Sharia Arbitration Council (BASYARNAS). After Decision of the Constitutional Court No. 93 of 2012 becomes strong in its jurisdiction to handle disputes and cases in religious jurisdictions; 2). In resolving disputes, Islamic economics obtains the following information: first, more religious courts have legal certainty than in BASYARNAS. Second, but the process in Religion is too long-winded, long and expensive, whereas in BASYARNAS it is simpler, easier and cheaper. Third, privacy at BASYARNAS is better protected than in open court. Fourth, the ability of judges in religious courts on religious matters is no doubt but economic cases may still need to be improved, while in BASYARNAS the arbitrators can be recruited from experts and practitioners in the field of Sharia law and economics. Fifth, and if religious equipment and organizational court facilities are completed, BASYARNAS may still need to be improved.

Considering the above conclusions, the authors noticed that the existing institutions the Religious Court and BASYARNAS both have advantages and disadvantages in dealing with Sharia economic disputes. It should be fostered openness of the various parties that prefer the Islamic Shura' (consensus) in determining everything and solve a problem. Through Shura' dispute can be resolved satisfactorily, still can maintain the privacy of the parties, the closer the relationship of the parties, the time can be shortened, more cost-efficient, and the relationship of the parties can be improved better.

If we find that the resolution of economic disputes, Sharia through BASYARNAS can be submitted before the dispute resolution through the Religious Courts. At the end of the conclusion, this article proposes a number of suggestions as mentioned below. First, Islam is the only religion that is good and perfect that the only proper life system to be implemented by humans as a caliph in the earth. Among the tangible evidence of the truth of Islam are the economic teachings of Sharia. Sharia can bring economic justice, comfort, security, safety and welfare of the human world and the hereafter. Unfortunately, not all 
people understand it, especially the Muslims themselves do not all understand let alone implement it. For that we need to be improved socialization application of Islamic Sharia Sharia economic particularly through sermons, proselytizing, and tausiyah in various groups and agencies. Even should also formed containers both in the realm of public and private institutions or community for the implementation of Islamic Sharia, especially economic Sharia.

Second, to anticipate and resolve problems in the application of Sharia as the uneven economic knowledge of Sharia in the economy as well as their users, it needs to be improved socialization and even training Sharia economy; still lack basic support legal and operational framework for the implementation of Sharia economy, it should be more intensified demands and legislation, rules and policies concerning the economic implementation of Sharia; and still lack the institutions implementing Sharia economy, it is necessary to continue to be made in various forums, institutions or community economic lover Sharia.

Third, in resolving economic disputes, Sharia needs to make some improvements involving human resources and facilities. It needs to be refined based on Sharia law and economic operations, consistency and independence rules for law enforcement; need to increase understanding of Sharia economics in public officials and law enforcement, especially in Religion and BASYARNAS; businesses need to be motivated to implement Sharia economics through policies that support the implementation of Sharia economics in our country; the need to improve the skills of judges and arbitrators to handle Sharia economic disputes; facilities need to improve the application of standard operating procedures for the resolution of Sharia economic disputes (SOP) and other supporting facilities; the public needs to provide political support to pro-Shariah leaders; and the community needs to participate.

\section{Acknowledgment}

This paper was presented at International Conference on Islamic Bussiness Law: Sharia Compliance held by Faculty of Law, Universitas Airlangga, October $25^{\text {th }}-26^{\text {th }}, 2017$. This paper is revised version after the conference.

\section{References}

Anwar, M., Yaswirman, \& Ulfanora. (2019). Dispute Resolution of Shariah Economy in Murahabah Financing Contract in Sahabat Mitra Sejati Cooperatives. International Journal of Multicultural and Multireligious Understanding, 6(3), 72-78.

Bahder, J. N. (2008). Metode Penelitian Ilmu Hukum. Bandung: Mandar Maju.

BASYARNAS. (2014). Profil dan Prosedur.

Manik, S. M. T., Yaswirman, Azheri, B., \& Ikhwan. (2017). Penyelesaian Sengketa Ekonomi Syariah Melalui Pengadilan Khusus Ekonomi Syariah di Lingkungan Peradilan Agama. Ahkam, 17(2), 435-448. https://doi.org/10.1017/CBO9781107415324.004

Masriani, Y. T. (2016). The Position of Notarial Deed in the Sharia Economic Dispute. Mimbar Hukum, 28(1), 162-173. https://doi.org/10.22146/jmh.15861

Masse, R. A., \& Rusli, M. (2018). Islamic Banking Dispute Resolution in National Sharia Arbitration Board. In IOP Conference Series: Earth and Environmental Science (Vol. 175, pp. 1-6). https://doi.org/10.1088/1755-1315/175/1/012169

Musjtari, D. N., Radliyah, N., \& Riyanto, B. (2019). The Mediation Process in Sharia Economic Dispute Resolution Through the Religious Court in Indonesia. Journal of Humanities and Social Science, 24(5), 39-47. https://doi.org/10.9790/08372405053947

Purwosusilo. (2013). Wawancara Dirjen Badan Peradilan Agama. Majalah Peradilan Agama.

Rasyid, R. (2010). Hukum Acara Pengadilan Agama. Jakarta: Raja Grafindo Persada.

Triana, N. (2017). Reconstructing Sharia Economic Dispute Resolution Based on Indonesian Muslim Society Culture. Ijtimā'iyya, 2(1), 107-128. https://doi.org/ 10.24090/ijtimaiyya.v2i1.1099

Triana, N. (2018a). Alternative Dispute Resolution Model in the AJB Bumiputera Life Insurance Company of Purwokerto in Shari'ah Perspectives. Al-'Adalah, 15(2), 367388. https://doi.org/10.24042/adalah.v15i2.3004

Triana, N. (2018b). Urgency of Arbitration Clause in Determining the Resolution of Sharia Economic Disputes. Jurnal Ilmu Syariah, 18(1), 65-88. 
UU-RI. Undang-Undang Nomor 30 Tahun 1999 Tentang Arbitrase dan Alternatif Penyelesaian Sengketa, Pub. L. No. 30 (1999). Republik Indonesia.

UU-RI. Undang-Undang Nomor 48 Tahun 2009 Tentang Kekuasaan Kehakiman, Pub. L. No. 48, Menteri Hukum dan Hak Asasi Manusia (2009). Republik Indonesia. https://doi.org/ 10.18860/ling.v5i1.609

UU-RI. Undang-Undang Nomor 50 Tahun 2009 Tentang Peradilan Agama, Pub. L. No. 50 (2009). Republik Indonesia.

Winata, F. H. (2012). Hukum Penyelesaian Sengketa: Arbitrase Nasional Indonesia dan Internasional. Jakarta: Sinar Grafika.

Yasin, M. N., Munir, M., Sukarmi, \& Sahibuddin. (2016). The Norm Reconstruction of Verdict Execution of the National Sharia Arbitration Board to Sharia Economic Dispute in Indonesia. Journal of Law, Policy and Globalization, 51(1), 49-63. Retrieved from www.iiste 